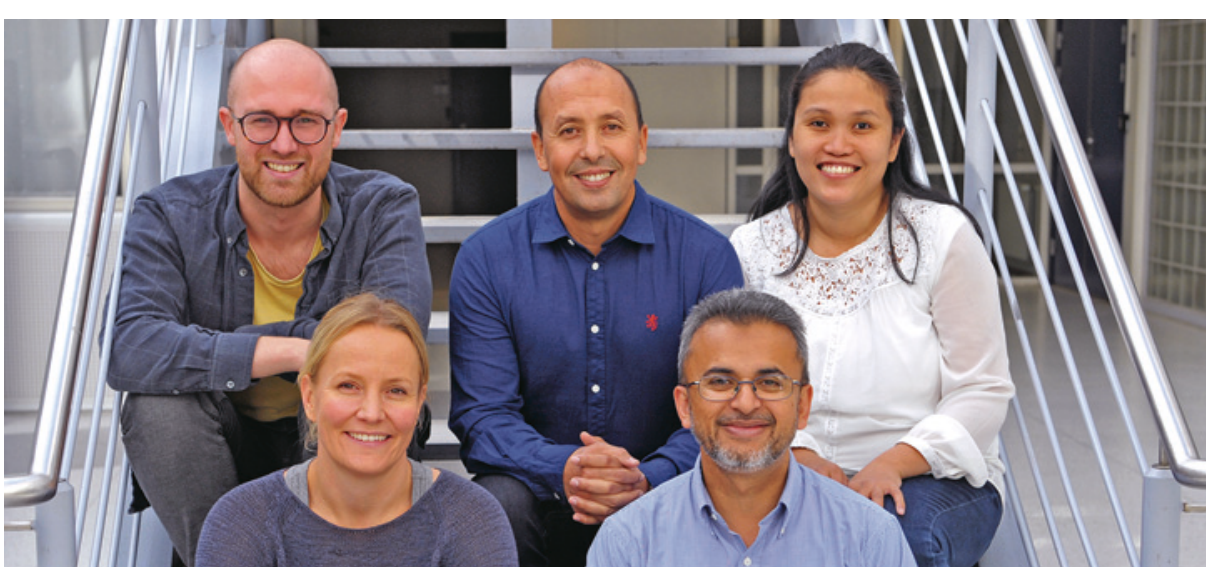

Øverst fra venstre Roar Fjær, El Hassan Hamdani og Marivi Nabong Moen. Nederst fra venstre Kaja Kristine Selmer og Farrukh Abbas Chaudhry. Foto: Gunnar F. Lothe

\title{
Funksjonsfeil i en kaliumkanal fører til epilepsi
}

Progredierende myoklonisk epilepsi kan være forårsaket av en genfeil som gir forstyrret nervecellefunksjon. Det viser en norsk studie.

Progredierende myoklonisk epilepsi karakteriseres av myoklone anfall og generaliserte tonisk-kloniske anfall. Sykdommen debuterer som regel i de første leveårene og er assosiert med progredierende tap av nevrologiske funksjoner, noe som gir kognitiv svikt og ataksier. Patofysiologien er ukjent. Norske forskere har studert genene til to brødre med typisk forløp av progredierende myoklonisk epilepsi, i en studie publisert i tidsskriftet Brain (1).

En ny mutasjon ble oppdaget i genet KCTD7 (Potassium Channel Tetramerization Domain 7) ved eksomsekvensering. Dette genet koder for et protein med hittil ukjent funksjon. Forskerne viste at KCTD7-proteinet finnes i cellemembranen, der det fungerer som en kaliumkanal som induserer hyperpolarisering i nerveceller. Proteinet regulerer også aktiviteten til en glutamintransportør som er viktig for danning av signalstoffet glutamat.

Funksjonelle studier av den aktuelle mutasjonen og fire andre patogene KCTD7-mutasjoner viste at disse fører til danning av intracellulære aggregater og opphevet kaliumfluks over cellemembranen. Dermed depolariseres nervecellene, noe som gir flere ukontrollerte elektriske utladninger, mer frigjøring av signalstoffer og dermed tap eller forfall av nerveceller. Mutasjonene fører også til at det dannes mindre glutamat. Dette forstyrrer den synaptiske signaleringen, svekker normale hjernefunksjoner og fører til utvikling av progredierende myoklonisk epilepsi.

- Dette er den første studien der man har kartlagt patofysiologien ved KCTD7-assosiert progredierende myoklonisk epilepsi, sier Farrukh Abbas Chaudhry, som er professor ved Universitetet i Oslo. - Studien gir oss ny forståelse av hvorfor denne formen for epilepsi har et så alvorlig forløp og er så behandlingsrefraktær, sier han.

- Det finnes over 15 proteiner i KCTDfamilien, og funksjonen til de fleste av dem er ukjent. Sannsynligvis er flere av dem essensielle for flere hjernefunksjoner, og de kan være involvert i patogenesen av andre epilepsiformer. Disse proteinene kan være fremtidige terapeutiske mål, sier Chaudhry.

\section{Tverrfaglig forskergruppe}

Forskningsgruppen til Farrukh Abbas Chaudhry består av molekylærbiolog Marivi N. Moen, elektrofysiolog El Hassan Hamdani og forskerlinjestudent Robin Johansen Menchini. Gruppen forsker på glutamintransport og metabolisme og hvordan dette bidrar til syntese av signalstoffer og nervesignalering i hjernen og hvordan disse funksjonene er involvert i utvikling av epilepsi, Parkinsons sykdom og demens.

Forsker Kaja Selmer og stipendiat Roar Fjær fra Dag Undliens forskningsgruppe ved Avdeling for medisinsk genetikk ved Oslo universitetssykehus utførte eksomsekvenseringen og identifiserte den nye mutasjonen. Jon K. Lærdahl ved kjernefasilitet for bioinformatikk ved Universitetet i Oslo utførte sekvensanalyser og strukturmodellering, og nevrolog Bjørnar Hassel ved Oslo universitetssykehus bidro til vurdering av det kliniske bildet og aminosyredataene til pasientene.

\section{Kaveh Rashidi}

Tidsskriftet

\section{Litteratur}

1. Moen MN, Fjær R, Hamdani EH et al. Pathogenic variants in KCTD7 perturb neuronal K+ fluxes and glutamine transport. Brain 2016. E-publisert 14.10.2016.
Ordforklaringer

Eksomsekvensering: Sekvensering av den delen av våre gener som koder for proteiner.

Myoklone anfall: Anfall med symmetriske rykkevise muskelsammentrekninger.

Generaliserte tonisk-kloniske anfall: Anfall med tilstivning av kroppen, etterfulgt av kramper som påvirker hele kroppen.

Ataksi: Forstyrrelser i muskelsamarbeidet i sammensatte bevegelser, noe som fører til usikre, ristende eller for voldsomme bevegelser.

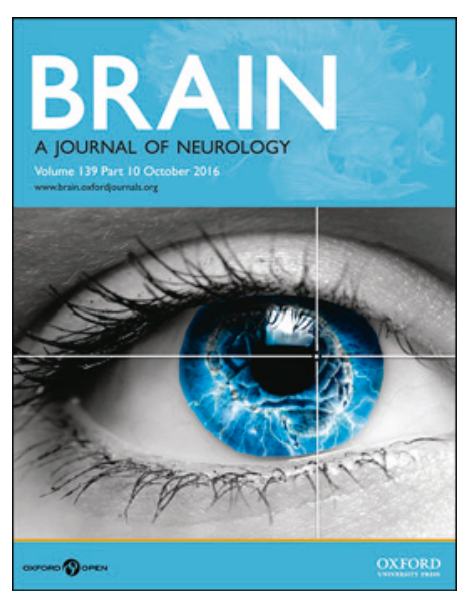

Artikkelen ble først publisert i tidsskriftet Brain i oktober 2016 